\title{
PEMURIDAN SEBAGAI UPAYA MENANAMKAN IMAN KEPADA KRISTUS PADA MAHASISWA STAK TERPADU PESAT SALATIGA
}

\author{
Melben Nainupu; Ahmad Tabrani; Frets Keriapy \\ GKI Tegalrejo; Sekolah Tinggi Agama Kristen Terpadu Pesat Salatiga; Sekolah Tinggi \\ Agama Kristen Terpadu Pesat Salatiga \\ Email: melbennainupu@gmail.com; ahmadpesat@yahoo.co.id; \\ fretskeriapy1106@gmail.com
}

\begin{abstract}
ABSTRAK
Perkembangan ilmu pengetahuan dan teknologi begitu cepat sehingga dapat memengaruhi kehidupan sosial baik individu dengan individu maupun kelompok. Manusia diperhadapkan dengan pola hidup yang beragam dan krisis gaya hidup merupakan suatu kondisi yang serius di era pasca modern saat ini. Oleh karena itu sangat penting bagi orang percaya dimuridkan agar memiliki karakter Kristus yang membawa pengaruh dalam bersosialisasi. Melihat masalah yang ada, maka tujuan dari penelitian ini adalah mendeskripsikan pemuridan sebagai upaya menanamkan iman kepada mahasiswa STAK Terpadu PESAT Salatiga dalam kepercayaan kepada Kristus. Metode yang digunakan dalam penelitian ini adalah kualitatif. Pengumpulan data melalui observasi dan wawancara serta teknik analisa data meliputi catatan lapangan, reduksi, display, dan kesimpulan. Keseluruhan responden dapat memahami dan ikut serta dalam proses pemuridan yang berlangsung dengan pemberian teladan hidup oleh pengikut Kristus. Dari hasil penelitian, ditemukan bahwa pemuridan dengan proses mentoring yang dilakukan oleh STAK Terpadu Pesat, dapat menanamkan iman mahasiswa kepada Kristus.
\end{abstract}

Kata kunci: Pemuridan, Iman, Kristus

\begin{abstract}
The development of science and technology is so fast that it can affect the social life of both individuals and groups. Humans are faced with diverse lifestyles and a lifestyle crisis is a serious condition in today's post-modern era. Therefore it is very important for believers to be discipled so that they have the character of Christ which influences their socialization. Seeing the existing problems, the purpose of this study is to describe discipleship as an effort to instill faith in students of the PESAT Integrated STAK Salatiga in their belief in Christ. The method used in this research is qualitative. Data collection through observation and interviews and data analysis techniques include field notes, reduction, display, and conclusions. All respondents can understand and participate in the process of discipleship that takes place by exemplifying life by followers of Christ. From the research results, it was found that discipleship with the mentoring process carried out by STAK Terpadu Pesat could instill students' faith in Christ.
\end{abstract}


Keywords: Discipleship, Faith, Christ

\section{PENDAHULUAN}

Fenomena kehidupan dalam masyarakat yang bebas menentukan kebahagiaan tanpa mengabaikan moralitas merupakan hal yang melatarbelakangi penelitian ini. Dapat dijumpai kasus - kasus yang berkaitan dengan moralitas melalui media massa seperti: percabulan, pembunuhan, pemerkosaan, narkotika dan lain sebagainya. Hal ini disampaikan oleh Frets dalam penelitiannya bahwa maraknya kejahatan yang terjadi, diakibatkan karena sistem pendidikan yang tidak ramah akan toleransi (Keriapy, 2020). Kecenderungan manusia hidup dengan kehendak bebas dapat membawa pribadi tersebut untuk menjalani kehidupan dengan sesuka hati tanpa memikirkan dampak dari tindakan yang dilakukan terhadap sesama ciptaan Allah.

Allah menciptakan manusia menurut gambar dan rupa-Nya (Kej.1:26-27) dan belum mengenal dosa karena Allah menciptakannya dengan sangat baik. Pengenalan akan dosa berawal ketika Adam dan Hawa melanggar apa yang menjadi ketetapan Allah sejak semula, yakni dengan memakan buah "pohon pengetahuan yang baik dan yang jahat" (Kej 2:16-17). Sebagai solusinya, Allah melakukan sesuatu kepada manusia dengan cara membuat pakaian manusia dari kulit binatang (Hwang, 2011).

Rencana kekal Allah untuk manusia adalah memantulkan karakter Allah. Hal ini dilakukan Yesus dengan memanggil murid-murid untuk mendapatkan pengetahuan dan kasih karunia, dan tidak hanya menjadi baik untuk diri sendiri tetapi bisa mengubah orang lain.

Manusia diperhadapkan dengan berbagai macam gaya hidup dan "krisis gaya hidup merupakan suatu kondisi yang serius di era pasca modern saat ini” (Halim, 2003). Hal ini terjadi karena perkembangan ilmu pengetahuan dan teknologi yang begitu cepat sehingga dapat memengaruhi kehidupan sosial baik individu dengan individu, individu dengan kelompok maupun kelompok dengan kelompok lainnya. Orang percaya hidup dalam keadaan yang dipengaruhi oleh perkembangan ilmu pengetahuan sehingga gaya hidup yang sesuai dengan firman Tuhan sangat dibutuhkan untuk memberi dampak bagi orang di sekitar.

Dalam perkembangan ilmu pengetahuan dan teknologi sebagaimana yang disinggung oleh Imbran Batelemba Bonde pada penelitiannya, menuntut upaya 
pengajaran pada Alkitab menjadi sebuah keharusan (Bonde, 2020). Martina dalam penelitiannya mengatakan bahwa spiritualitas kekristenan haruslah menyentuh segala aspek baik dalam bidang pendidikan, maupun emosi (Novalina, 2020). Sebaliknya, diungkapkan Elia Tambunan bahwa intelektualitas pada Perguruan Tinggi mengalami obesitas khususnya dalam hal teologi namun secara keilmuan tidak. Tidak hanya itu, Perguruan Tinggi pun tidak boleh melupakan tindakan sosial sebagai sebuah tanggungjawab (Tambunan, 2020). Hal lain pun dikatakan oleh Nuhamara bahwa setiap Pendidikan dalam segala konteks harusnya menyentuh karakter setiap nara-didik (Nuhamara, 2018). Tampak jelas dari beberapa penelitian ini, belum menyentuh bagaimana seharusnya sebagai mahasiswa yang fokus pendidikannya pada Pendidikan Agama Kristen dan Teologi, harus melakukan pemuridan. Hal ini perlu untuk dilakukan guna untuk menanamkan iman kepada Kristus, sebagai pembentukan karakter Kristus yang terimplementasi dalam kehidupan pada mahasiswa Pendidikan Agama Kristen dan Teologi. Sebagaimana yang dikatakan oleh Gunawan bahwa kedewasaan rohani sangat dibutuhkan supaya karakter Kristus nampak dalam kehidupan setiap hari (Gunawan, 2017).

Dalam dunia pendidikan, seringkali terjadi gemelut yang tidak kunjung selesai, di mana pemerataan pendidikan masih hanya sebuah mimpi yang tidak kunjung terimplementasikan (Keriapy, 2020). Pendidikan yang selama ini dijalani untuk mengejar hasil atau pencapaian dan lebih banyak mengabaikan pemberian teladan hidup. Tidak mengherankan, jika kebanyakan orang yang sering dijumpai di tengah masyarakat sangat cerdas dalam berteori namun karakter yang menjadi cermin pribadi cenderung negatif. Krisis kehidupan demikian yang perlu ditemukan solusinya tanpa mengabaikan nilai-nilai dalam kekristenan.

PESAT melaksanakan berbagai program dan salah satu yang diteliti adalah pemuridan yang berlangsung di Sekolah Tinggi Agama Kristen (Selanjutnya: STAK) Terpadu Pesat Salatiga. STAK Terpadu Pesat Salatiga sendiri memiliki visi dan misi. Visi STAK Terpadu PESAT Salatiga adalah menjadi lembaga pendidikan tinggi dengan menyelenggarakan kegiatan pendidikan dan penelitian dan pengabdian kepada masyarakat desa untuk memperlengkapi/ menghasilkan pemimpin-pemurid. Sedangkan misinya adalah (1) Menyelenggarakan Pendidikan Tinggi Agama Kristen dan Tridarma Perguruan Tinggi; (2) Menyelenggarakan Pendidikan Agama Kristen Untuk 
Membangun Generasi Pemimpin Transformatif; (3) Menyelenggarakan Penelitian Tentang Pendidikan Agama Kristen dan Kepemimpinan Anak Secara Ilmiah, Kritis dan Aplikatif; (4) Menyelenggarakan Pengabdian Kepada Masyarakat Melalui Pendidikan Anak Desa.

Panggilan pemuridan harus diterima sebagai norma bagi setiap orang Kristen dan hal tersebut harus dimulai dengan pemahaman untuk meneladani Yesus (Neil, 2012). Itulah mengapa, melihat latar belakang masalah yang penulis paparkan dan visi misi dari PESAT sendiri, maka penelitian ini bertujuan untuk mengupayakan proses menanam iman kepada Kristus melalui pemuridan yang dilakukan oleh STAK Terpadu Pesat Salatiga kepada mahasiswa/I melalui pembimbingan dalam hidup bersama dengan pola pemuridan yang diterapkan di STAK Pesat Salatiga.

\section{METODE}

Metode yang digunakan adalah kualitatif. "Metode penelitian kualitatif adalah metode penelitian yang digunakan untuk meneliti pada kondisi obyek yang alamiah" (Sugiyono, 2016). Selanjutnya narasumber dalam penelitian ini tidak diambil secara acak, tetapi bersifat snowball (Sugiyono, 2016). Dalam penelitian ini, narasumber yang diambil adalah semua mahasiswa semester 3 yang berjumlah 11 orang karena mereka telah melewati proses mentoring selama 3 semester (1,5 tahun). Sedangkan pengumpulan data dalam penelitian ini melalui observasi dan wawancara karena dianggap dapat memberikan informasi yang dibutuhkan peneliti. observasi yang dilakukan terhadap narasumber adalah dengan "pengamatan terhadap objek secara cermat di lokasi penelitian, serta mencatat secara sistematis mengenai gejala-gejala yang diteliti berupa tempat, pelaku, kegiatan, objek, perbuatan, waktu untuk memberikan gambaran realistik" (Mardawani, 2020). Sedangkan wawancara dalam penelitian ini adalah wawancara terstruktur. "Wawancara terstruktur digunakan sebagai teknik pengumpulan data, apabila peneliti atau pengumpul data telah mengetahui dengan pasti tentang informasi apa yang diperoleh. Selain membawa instrument sebagai pedoman wawancara, pengumpul data juga dapat menggunakan alat bantu seperti tape recorder, camera, gambar, brosur, dan benda lain yang dapat membantu dalam proses kegiatan wawancara" (Mardawi, 2020). 


\section{HASIL DAN PEMBAHASAN}

Pada bagian ini, penulis memisahkan antara Hasil dan Pembahasan

\section{Pemuridan Pada Mahasiswa STAK Terpadu}

Data yang diuraikan merupakan hasil wawancara yang diolah dari bahasa seharihari menjadi bahasa ilmiah berdasarkan responden dari mentor dan murid dari lapangan untuk menggambarkan proses pemuridan yang berlangsung di STAK Terpadu Pesat Salatiga.

Bill Hull mengatakan bahwa sebuah komunitas dalam hal ini gereja yang melakukan pemuridan, harusnya dimulai dengan membangun hubungan dengan Tuhan maupun dengan sesama (Hull, 2010). Dia pun melanjutkan dengan mengatakan bahwa setiap murid Kritus, hidup dalam doa bersama, bersekutu bersama dan berbagi (Hull, 2010). Proses pemuridan pada mahasiwa STAK Terpadu PESAT Salatiga meliputi dua aspek penting yaitu aspek berbagi hidup dan aspek pengajaran.

\section{Aspek Berbagi Hidup}

Wawancara yang dilakukan terhadap mentor dan pengajar terkait aspek berbagi hidup adalah membagi hidup yang dimulai dari diri pengajar atau mentor seperti; unggul, integritas, inovasi, berani, kerjasama tim, hidup bersama, bertumbuh, saling membentuk karakter, saat teduh, kerja bakti, sehingga adanya keselarasan antara perkataan dan perbuatan dari pengikut Kristus lainnya kepada mahasiswa yang dibimbing. Sedangkan aspek berbagi hidup yang dimaksudkan oleh mahasiswa adalah teladan hidup yang dipelajari dari pengikut Kristus lainnya melalui kesederhanaan dalam memimpin, integritas, sopan, jujur, sabar, rendah hati, penasehat, motivator, peduli dengan sesama, memiliki hubungan pribadi dengan Tuhan, bertanggungjawab, disiplin, sikap toleransi, pekerja keras serta dalam berbicara.

Dalam observasi, peneliti melihat bahwa pemberian teladan oleh mentor dan pengajar di lingkungan STAK Terpadu Pesat Salatiga tidak ada penyimpangan sosial baik terhadap individu maupun kelompok. Mahasiswa dibimbing untuk bekerja sama dan saling peduli terhadap orang lain. Proses pemberian teladan ini bertujuan untuk membangun karakter mahasiswa yang dibenturkan dengan perkembangan zaman serta tuntutan gaya hidup pada era modern saat ini. 
Dari hasil wawancara dengan pengajar, mentor dan mahasiswa yang diuraikan di atas maka dapat dijelaskan bahwa aspek berbagi hidup mahasiswa dalam kehidupan setiap hari dengan pola pondok (baca: asrama), di mana setiap pondok memiliki mentor, di mana mentor tersebut hidup bersama mahasiswa. Kehidupan di pondok dengan pola mentoring yang diterapkan menjadikan mahasiwa dengan sukacita berbagi apa yang dimiliki kepada sesamanya yang berada di pondok. Berbagi hidup dikatakan seperti hidup bersama dalam sebuah pondok baik mentor maupun mahasiswa, saling berbagi apabila ada dari mahasiswa yang berkekurangan, makan bersama, dll.

\section{Aspek Pengajaran}

Hasil wawancara yang dilakukan terhadap mentor dan pengajar maka aspek pengajaran yang dimaksud adalah materi yang disampaikan kepada mahasiswa meliputi kerohanian, pengalaman, relasi dengan orang lain dan pengajaran, berpusat pada Kristus, komunitas, karakter, kompetensi serta belajar tentang nilainilai PESAT, belajar tentang karakter-karakter Kristus untuk meningkatkan iman dan firman Tuhan menjadi dasar. Sedangkan aspek pengajaran menurut mahasiswa adalah proses penyampaian materi yang berlangsung di kelas pemuridan oleh pengajar, mentor, dengan kegiatan-kegiatan yang dimulai dengan berdoa, pujian penyembahan, permainan dan penyampaian materi. Adapun pembelajaran yang disampaikan menurut responden adalah pertobatan, karakter yang baik, mengatasi masalah, akar kesombongan, kerendahan hati, kejujuran, itegritas, mentoring, membaca Alkitab, belajar berdoa, sabar serta mengatasi masalah tangkah laku yang tidak baik.

Melalui observasi yang telah dilakukan, peneliti menemukan bahwa pengajar dan mentor menyiapkan materi-materi yang telah dikhususkan untuk menolong mahasiswa melalui diskusi yang dimulai dengan doa, menyanyi, dan pembacaan Alkitab. Hal ini dilakukan dengan mengikuti jadwal dan materi yang diberikan oleh pihak sekolah. Oleh karena itu, semua mahasiswa mengikuti proses pemuridan dengan topik pembahasan yang sama di setiap sesi kemudian mahasiswa diajak untuk mengemukakan pendapat secara bergantian serta menceritakan pengalaman yang dialami baik di dalam kampus maupun di tempat pelayan dengan tujuan saling memberi masukan dan mengevaluasi. 
Dari hasil pemaparan di atas maka pengajaran yang dimaksudkan oleh mentor, pengajar, dan mahasiswa adalah terjadinya proses belajar mengajar secara kelompok dan berdiskusi di kelas pemuridan dan pondokan yang dimulai dengan doa, pujian penyembahan, permainan, penyampaian materi berdasarkan Alkitab dan telah diatur sedemikian rupa secara terus menerus diterapkan di STAK Terpadu Pesat Salatiga dengan tujuan menjadikan hamba Tuhan berkarakter Kristus. Dari hal-hal yang dilakukan inilah, proses penanaman iman kepada Kristus kepada mahasiswa dapat berjalan dengan efektif.

\section{Iman Kepada Kristus Pada Mahasiswa Stak Terpadu}

Data yang diuraikan merupakan hasil wawancara yang diolah dari bahasa seharihari menjadi bahasa ilmiah berdasarkan responden dari mentor dan murid dari lapangan untuk menggambarkan proses pemuridan yang berlangsung di STAK Terpadu Pesat Salatiga. Berkaitan dengan iman kepada Kristus, ada tiga aspek penting yaitu aspek keyakinan yang teguh kepada Yesus Kristus, aspek pertumbuhan rohani, dan aspek hubungan pribadi dengan Tuhan.

\section{Aspek Keyakinan yang Teguh kepada Yesus Kristus}

Hasil wawancara yang dilakukan terhadap mentor dan pengajar maka aspek keyakinan yang teguh dalam Yesus Kristus yang dimaksud adalah meyakini jaminan keselamatan dalam Yesus, yakin bahwa Yesus telah menebus dosa manusia dan percaya dengan sungguh-sungguh bahwa Yesus adalah Tuhan sebagai suatu keyakinan yang kokoh. Sedangkan menurut mahasiswa, keyakinan teguh kepada Yesus Kristus berarti mempunyai harapan secara pribadi baik itu masa depan, melayani Tuhan, menjadi berkat bagi orang lain, melayani anak di desa dan bangsa.

Melalui observasi yang telah dilakukan, peneliti menemukan bahwa semua mahasiswa memiliki keyakinan teguh kepada Yesus Kristus bukan sekedar tahu di kepala saja namun hal itu didasarkan dengan pengalaman iman yang disaksikan melalui ibadah komunitas, ibadah pondokan/ asrama, dan juga dinyatakan dalam hidup bersama. Sehingga dapat disimpulkan bahwa keyakinan yang teguh kepada Kristus menurut mentor, pengajar dan mahasiswa adalah suatu keyakinan teguh yang timbul dari dalam hati kepada Kristus sebagai Tuhan yang telah menebus 
dosa manusia dan memberikan jaminan keselamatan kepada setiap pengikut-Nya serta memiliki pengharapan.

\section{Aspek Pertumbuhan Rohani}

Pertumbuhan rohani yang dimaksudkan oleh mentor dan pengajar melalui wawancara adalah hidup yang biasa-biasa saja dan hanya mengetahui Yesus sekedar itu saja dengan sesuka hati telah menjadi seorang murid Kristus yang sungguh-sungguh mengenal dan bertumbuh dalam Tuhan serta mengalami perubahan karakter dari perkataan, perbuatan harus konsisten dan memiliki tujuan hidup bersama Kristus. Sedangkan aspek pertumbuhan rohani yang dimaksud oleh mahasiswa melalui wawancara adalah terjadinya perubahan hidup yang berlangasung dalam proses pemuridan. Dimulai dari kehidupan yang biasa-biasa saja dengan sesuka hati seperti minder, dendam, tidak menerima teguran, hidup hancur-hancuran, tidak memiliki waktu untuk doa pribadi menjadi pribadi yang bertumbuh melalui pembelajaran dalam kelas pemuridan dan perubahan karakter serta pertumbuhan kerohanian.

Hasil wawancara yang dilakukan oleh penulis, menemukan bahwa pertumbuhan rohani terjadi dari perubahan hidup/ karakter oleh mahasiswa yang sebelumnya minder, pendendam, pemarah, dan lain sebagainya menjadi pribadi yang memiliki karakter baik seperti; integritas, jujur, berani, berbagi hidup dan lain sebagainya setelah mengenal Kristus. Melalui observasi yang dilakukan, peneliti menemukan mahasiswa mengalami pertumbuhan kerohanian yang dapat dilihat dari perubahan karakter yang terus dipertahankan baik dalam lingkup sekolah, masyarakat, maupun tempat di mana mahasiswa diutus untuk melayani. Peneliti melihat adanya keseriusan mahasiswa dalam mengikuti proses pemuridan yang kemudian berbuah pada karakter baik.

\section{Aspek Hubungan Pribadi dengan Tuhan}

Hubungan pribadi dengan Tuhan merupakan suatu hal yang wajib dilakukan oleh seorang pengikut Kristus. Sehingga untuk membangun hubungan pribadi dengan Tuhan perlu komitmen dari setiap pribadi. Sehingga observasi dan wawancara dilakukan kepada mahasiswa dalam hal komitmen untuk memiliki waktu pribadi dan berkomunikasi dengan Tuhan melalui rutinitas spiritual sangat penting. Hubungan pribadi dengan Tuhan berlangsung secara dinamis. 
Hasil observasi dan wawancaya yang telah dilakukan, dapat dikatakan bahwa hubungan pribadi dengan Tuhan yang dimaksudkan adalah kegiatan yang dinamis antara individu dengan Tuhan melalui saat teduh, pembacaan Alkitab, rajin berdoa. Walaupun ada mahasiswa yang mengatakan bahwa dirinya kurang rajin dan ada juga yang jarang membaca Alkitab. Kegiatan ini dilakukan oleh mahasiswa di STAK Terpadu Pesat Salatiga setiap hari dengan mengikuti jadwal yang telah ditetapkan oleh pihak institusi. Ada lima orang responden yang mengatakan kurang rajin dalam membaca Alkitab namun enam orang responden lain mengatakan rajin dan sungguh-sungguh. Melalui observasi yang dilakukan, peneliti menemukan bahwa tidak semua mahasiswa sungguh-sungguh dalam membangun hubungan yang dinamis dengan Tuhan sesuai jadwal yang ditetapkan. Namun, setiap mahasiswa memiliki waktu pribadi untuk membangun hubungan yang dinamis dengan Tuhan baik itu di pondok/ asrama maupun di ruang doa yang telah disediakan oleh pihak sekolah. Kebiasaan tersebut (saat teduh, membaca Alkitab, berdoa) terus dilakukan dan berlangsung di pondok Sekolah Tinggi Agama Kristen Terpadu Pesat Salatiga.

\section{PEMBAHASAN}

Penelitian ini dilakukan untuk menggambarkan proses pemuridan yang berlangsung di STAK Terpadu Pesat Salatiga serta menjelaskan tentang iman kepada Kristus dengan mengekspresikan karakter Kristus seperti rendah hati, melayani, mengasihi oleh setiap mahasiswa khususnya semester 3 tahun ajaran 2018/2019.

\section{Proses Pemuridan}

Menurut Togi Simanjuntak, pemuridan adalah kegiatan yang dikerjakan perorangan dalam hal mendidik, mengajar dan membimbing orang lain untuk belajar melakukan apa yang dikerjakan pengajarnya atau pembimbingnya (Simanjuntak, 2012). Pemuridan berasal dari kata murid. Kata murid dalam bahasa Yunani adalah Mathetes artinya adalah orang yang diajar (S, 2016). Menurut Dennis McCallum dan Jesisca Lowery pemuridan dikatakan proses pembentukan seorang rabi baru secara utuh, sang rabi senior membagikan segala sesuatu yang dimilikinya seperti: karakternya, pengetahuannya, nilai-nilainya dan hikmatnya (McCallum \& Lowery, 2015). Menurut Bill Hull pemuridan (discaple- 
making) berasal dari kata kerja matheteusate yang berarti membuat atau menjadikan murid (Hull, 2014). Tujuan dari pemuridan adalah untuk menghasilkan orang dengan kepribadian tertentu (McCallum \& Lowery, 2015). Pemuridan terjadi saat seseorang yang dapat menolong orang lain (Bill, 2007). Sehingga "inti dari seorang murid adalah mencakup hidup dalam kesatuan intim dalam Kristus dan berlangsung setiap hari” (Hull, 2014). Robby Gallaty mengatakan bahwa pemuridan berfokus pada belajar dari sang guru dan berjalan mengikuti kehidupannya (Gallaty, 2015).

Dari uraian para ahli di atas maka dapat disimpulkan bahwa pemuridan adalah suatu upaya untuk terjadinya proses pertumbuhan rohani (pertumbuhan pengetahuan, iman dan ketaatan) seorang pengikut Kristus yang dilakukan pengikut lainnya dengan cara membagikan segala sesuatu yang dimiliki seperti: karakter, pengetahuan, nilai-nilai dan hikmat untuk menjadikan seseorang serupa dengan Kristus. Dengan indikator: berbagi hidup, pengajaran, pertumbuhan rohani dan perubahan karakter.

Dari hasil penelitian, maka data yang ditemukan adalah keseluruhan responden dapat memahami dan ikut serta dalam proses pemuridan yang berlangsung dengan pemberian teladan hidup oleh pengikut Kristus lainnya yang dianggap bisa membimbing, memotivasi, menasehat, mendorong setiap mahasiswa memiliki karakter seperti; integritas, jujur, berani, sopan, bertanggung jawab, pekerja keras, agar bertumbuh bersama melalui kegiatan-kegiatan yang telah diatur oleh Sekolah Tinggi Agama Kristen Terpadu PESAT dengan menjunjung tinggi nilai PESAT yaitu; integritas, unggul, berani, inovasi, kerjasama tim untuk bertumbuh bersama dari lingkup kelompok menjadi pribadi dalam kehidupan yang terus berlangsung.

Proses pemuridan yang telah dilakukan oleh STAK Terpadu PESAT Salatiga terhadap mahasiswa melalui mentor dalam mendidik, membimbing dan mengajarkan setiap individu untuk melakukan apa yang telah lebih dahulu dilakukan oleh mentor dapat dikatakan sesuai dengan pengertian pemuridan menurut para ahli dan indikator yang diuraiakan di atas. "Gaya hidup diumpamakan sebagai garam dan terang dunia. Dua analogi ini digunakan Yesus untuk mengajar murid-murid bersaksi atau memberitakan Injil melalui sikap 
hidup. Sekaligus Kristus memberikan teladan" (Halim, 2003). Sehingga setiap murid yang dibimbing melalui pola pemuridan seperti ini akan berpatokan pada teladan hidup yang mencerminkan karakter Kristus.

\section{Iman kepada Kristus}

"Di dalam Perjanjian Lama kata iman berasal dari kata kerja aman yang berarti memegang teguh. Dalam Perjanjian Baru, iman berarti mengamini dengan segenap kepribadian dan cara hidupnya kepada janji Allah, bahwa ia di dalam Kristus. Sehingga segenap hidupnya dikuasai oleh keyakinan yang demikian (Hadiwijono, 2007). Selanjutnya gereja harus melayani umat Allah dalam upaya untuk meneguhkan panggilan dan iman yang Kristus telah berikan (Pakpahan, 2020).

Menurut kamus Webster “ iman adalah keyakinan, kepercayaan dan kesetiaan kepada Allah" (Hickey, 2007). Menurut Ravi Zacharias “iman adalah keyakinan kepada pribadi Yesus Kristus dan kuasa-Nya” (Zacharias, 2011). Sedangkan Eddy Leo menjelaskan arti iman kepada Kristus dengan "membiarkan Kristus orang percaya sebagai alat untuk melayani” (Leo, 2012).

Dari uraian para ahli di atas maka dapat disimpulkan bahwa iman kepada Kristus adalah keyakinan kepada Yesus Kristus yang timbul di dalam hati melalui interaksi dinamis antara roh manusia dengan Tuhan sebagai dasar yang teguh dari semua hal yang diharapkan dan bukti dari semua hal yang tidak dilihat sebagai bentuk jaminan keselamatan yang kekal. Dengan indikator : hubungan pribadi dengan Tuhan, keyakinan yang teguh dan pengharapan dalam Yesus Kristus.

Karakter Kristus merupakan suatu kata yang tidak asing bagi setiap orang yang beriman kepada Yesus. Allah yang berinkarnasi dalam Yesus Kristus datang ke dunia ini untuk menjadikan diri-Nya sebagai teladan. Sehingga setiap orang percaya berkewajiban mengikuti teladan yang sudah diberikan melalui pengajaran-pengajaran dalam Alkitab. Untuk memahami karakter Kristus bagi orang percaya sebagai gaya hidup maka adapun ciri-ciri yang sesuai dengan keteladanan Yesus kepada murid antara lain: 1) Rendah hati. "Kerendahan hati dimulai dan diakhiri dengan penghargaan orang percaya terhadap diri sendiri. Ini adalah untuk menyadari ketidak layakan orang percaya dengan penghargaan mental dan untuk menghargai orang lain dari pada diri sendiri” (Bailey, 2002). 2) 
Melayani. "Yesus memberikan suatu perbandingan yang kontras kepada muridmurid-Nya untuk menolong para murid mengerti sikap yang tidak boleh dan yang harus mereka miliki" (Ronald, 2004). Orang yang melayani memiliki ciri khas untuk inisiatif melaksanakan sesuatu tanpa ada unsur paksaan melainkan kerelaan dan tulus. Dalam artian orang yang melayani butuh inisiatif dari pribadi orang tersebut. 3) Mengasihi dimana kerelaan untuk diubah menjadi seperti Yesus Kristus berarti ada kemauan untuk bersifat terbuka dan bersikap tabah. Sehingga hal mengasihi menjadi sesuatu yang mendasar sebagai seorang murid Kristus dalam mengimplementasikannya pada kehidupan.

Melalui hasil penelitian maka keseluruhan narasumber dapat mempelajari gaya atau keteladanan hidup yang lebih dahulu diberikan oleh mentor kepada mahasiswa melalui kehidupan bersama dalam lingkup komunitas ke lingkup pribadi. Dalam hal hubungan pribadi dengan Tuhan, peneliti menemukan lima narasumber menyatakan memiliki hubungan pribadi dengan Tuhan namun kurang dalam pembacaan Alkitab sedangkan enam responden lainnya menjelaskan secara baik tentang hubungan khusus dengan Tuhan yang meliputi saat teduh pribadi, pembacaan Alkitab, rajin berdoa, sehinggal muncul keyakinan yang teguh dari dalam hati akan keselamatan dari Yesus Kristus, yakin akan penebusan dosa dari Yesus Kristus dan percaya bahwa Yesus adalah Tuhan yang timbul melalui hubungan interaksi yang dinamis oleh setiap mahasiswa dan menyatakan bahwa masing-masing pribadi memiliki perubahan hidup dari hidup yang biasa-biasa saja menjadi hidup berkarakter baik setelah menjadi murid Kristus serta komitmen untuk melayani Tuhan dan menjadi berkat bagi orang lain terutama anak-anak di desa dengan membagi pengetahuan dan pengenalan akan iman kepada Kristus dalam hidup sehari-hari.

Dari hasil analisa peneliti, maka dapat dikatakan bahwa setiap mahasiswa bisa memahami arti iman kepada Kristus seperti yang diuraikan menurut pendapat para ahli beserta indikator di atas dengan memiliki keyakinan yang teguh kepada Kristus sebagai bentuk jaminan keselamatan melalui hubungan pribadi dengan Tuhan yang meliputi saat teduh, membaca Alkitab, berdoa, serta pertumbuhan karakter walaupun ada lima responden yang masih kurang rajin dalam membaca Alkitab. 


\section{SIMPULAN}

Proses pemuridan yang telah dilakukan oleh STAK Terpadu PESAT Salatiga terhadap mahasiswa melalui mentor terjadi pertumbuhan rohani (pertumbuhan pengetahuan, iman dan ketaatan) seorang pengikut Kristus yang dilakukan pengikut lainnya dengan cara membagikan segala sesuatu yang dimiliki seperti: karakter, pengetahuan, nilai-nilai dan hikmat untuk menjadikan seseorang serupa dengan Kristus. Dengan indikator : berbagi hidup, pengajaran, pertumbuhan rohani dan perubahan karakter dan memiliki dampak bagi mahasiswa dalam hal pertumbuhan iman kepada Kristus melalui perubahan karakter serta memiliki keyakinan yang teguh kepada Kristus. Dampak dari proses pemuridan yang terjadi pada mahasiswa selama mengikutinya, secara praktis akan memiliki gaya hidup berkarakter dengan mengutamakan nilai-nilai Kristiani untuk memberi pengaruh positif pada kehidupan bermasyarakat.

\section{DAFTAR PUSTAKA}

Bailey, B. J. (2002). Prajurit Kristus. Harvest Publication.

Bill, L. (2007). Effektive Pastoring-Mengembalakan Dengan Hati. Yogyakarta: Andi. Bonde, I. B. (2020). Kembali ke Akar: Pendidikan Kristen dalam Menghadapi Isu Perubahan Iklim, Perang, dan Keterbatasan Akses Pendidikan. 1(2), 196-213. https://doi.org/10.47530/edulead.v1i2.46

Gallaty, R. (2015). Rediscovering Discipleship. Perkantas.

Gunawan, A. (2017). Pemuridan dan Kedewasaan rohani. Jurnal Theologia Aletheia, 19(12).

Hadiwijono, H. (2007). Iman Kristen. Jakarta: BPK Gunung Mulia.

Halim, M. (2003). Model-model penginjilan Yesus: Suatu penerapan masa kini. Penerbit Gandum Mas.

Hickey, M. (2007). Iman yang Membuat Doa Terjawab. ANDI.

Hull, B. (2010). The disciple-making church: Leading a body of believers on the journey of faith. Baker Books.

Hull, B. (2014). Panduan Lengkap Pemuridan. Yogyakarta: Yayasan Gloria.

Hwang, T. (2011). Kristologi. ANDI. 
Keriapy, F. (2020). Pendidikan Kristiani Transformatif Berbasis Multikultural dalam Konteks Indonesia. REGULA FIDEI: Jurnal Pendidikan Agama Kristen, 5(2), 82-93. https://doi.org/10.46307/rfidei.v5i2.55

Leo, E. (2012). Build My Home One On One. Metanoia.

McCallum, D., \& Lowery, J. (2015). Organic discipleship. Surabaya: Literatur Perkantas Jawa Timur.

Neil, H. (2012). Imagine Church. Perkantas.

Novalina, M. (2020). Spiritualitas Orang Kristen Dalam Menghadirkan Kerajaan Allah Di Tengah Tantangan Radikalisme. Jurnal Teologi Kontekstual Indonesia, 1(1), 26-37. https://doi.org/10.46445/jtki.v1i1.293

Nuhamara, D. (2018). Pengutamaan Dimensi Karakter Dalam Pendidikan Agama Kristen. Jurnal Jaffray, 16(1), 93-114.

Pakpahan, G. K. R. (2020). KARAKTERISTIK MISI KELUARGA DALAM PERSPEKTIF PERJANJIAN LAMA. VOX DEI: Jurnal Teologi Dan Pastoral, $1(1), 16-36$.

Ronald, L. W. (2004). Melayani Dengan Efektif. Jakarta: BPK Gunung Mulia.

S, J. (2016). Eklesiologi. ANDI.

Simanjuntak, T. (2012). The Art of Mentoring. Jakarta: Metanoia.

Sugiyono. (2016). Metode Penelitian Pendidikan (Pendekatan Kuantitatif, kualitatif dan $R \& D)$. Alfabeta.

Tambunan, E. (2020). PENDIDIKAN PROGRESIF DAN KAUM URBAN: MENCARI WAJAH BARU KONTRIBUSI SOSIAL. EDULEAD: Journal of Christian Education and Leadership, 1(1), 56-76. https://doi.org/10.47530/edulead.v1i1.27

Zacharias, R. (2011). Jesus Among Other Gods. Pionir Jaya. 